International Journal of Linguistics, Literature and Translation

ISSN: 2617-0299 (Online); ISSN: 2708-0099 (Print)

DOI: $10.32996 / \mathrm{ijllt}$

Journal Homepage: www.al-kindipublisher.com/index.php/ijltt

IJLLT

\title{
Teaching English through Educational Games in Yemeni High School Classes
}

\author{
Ameen Ghyama \\ Research Scholar, Faculty of Languages, Letters and Arts, Bin Tofail University, Kenitra, Morocco
}

$\square$ Corresponding Author: Ameen Ghyama, E-mail: alghyam2015@gmail.com

\section{ARTICLE INFORMATION ABSTRACT}

Received: 15 September 2021

Accepted: 25 October 2021

Published: 30 November 2021

DOI: $10.32996 /$ ijllt.2021.4.11.6

\section{KEYWORDS}

Educational Games, Teaching

English, learning styles and

strategies, EFL
This study is an investigation of the educational games used in Yemeni high school classes. The main objective is to find out the extent to which Yemeni teachers are aware of the utility described in the theoretical part and whether they make use of EFL games in their classes while teaching English. Equally, this study tries to probe into some of the Yemeni EFL learners' viewpoints towards using EFL games in the learning processbesides shedding light on the types of games they generally prefer. The approach I used was purely quantitative in nature, but I also relied on the qualitative approach. Twenty teachers and one hundred high school students were given a questionnaire about using games in English teaching and learning. The results were analyzed and show that games can be a unique opportunity for teachers to teach meaningfully and communicatively English in real-life contexts as well as the learners encourage and increase cooperation and collaboration among them and acquire the vocabulary easily. Using English teaching EFL games, in my opinion, can mitigate such difficulties facing Yemeni teachers in teaching English. Carefully choosing the right games can help a great deal in encouraging students to learn avidly. Furthermore, good EFL games have a great role to play in creating a stress-free learning atmosphere, and at the same time make it possible for students to practice the desired language skills. The key significance is that games are not mere time-fillers; rather, this study tries to guide and help teachers see when to use games, how to choose games that cater to students' needs and interests. Based on these results, some practical recommendations were formulated in order to enhance Yemeni EFL teaching and learning through using games.

\section{Introduction}

English in Yemen is still taught via outmoded language teaching methods and strategies as such as the use of translation and memorization of long lists of vocabulary. In other terms, the emphasis is heavily placed on the teaching of grammatical points at the cost of other skills as writing, listening, etc. The absence of good in-service training on the part of teachers is also a serious problem. This study also hypothesizes that the use of games in teaching English will catapult the teaching and learning of English to a better position, thanks to the application of a new and effective method. Therefore, the introduction, development, and implementation of educational games in Yemeni EFL classes are in demand. Using English teaching EFL games, in my opinion, can mitigate such difficulties facing Yemeni teachers in teaching English. Carefully choosing the right games can help a great deal in encouraging students to learn avidly. Good EFL games have a great role to play in creating a stress-free learning atmosphere and at the same time make it possible for students to practice the desired language skills. These games can be a unique opportunity for teachers to teach meaningfully and communicatively English in real-life contexts. They also encourage and increase cooperation and collaboration among learners.

\subsection{Objectives of the study}

The major objective of this study is to highlight the importance of using games in EFL teaching in the Yemeni context. It throws some light on some of the main advantages and benefits of games in EFL classes, namely affective strategies, cognitive strategies, class dynamics, and adaptability. Moreover, it will show why, when, and how to use EFL games. It also touches upon the utility of

Copyright: (C) 2021 the Author(s). This article is an open access article distributed under the terms and conditions of the Creative Commons Attribution (CC-BY) 4.0 license (https://creativecommons.org/licenses/by/4.0/). Published by Al-Kindi Centre for Research and Development, London, United Kingdom. 
using games by taking into account two vantage points, mainly that of students and teachers. The present study also introduces, explains, and discusses some examples and criteria for using games that Yemeni EFL teachers can adjust and apply to their teaching environment.

\subsection{Questions of the study}

The current study tries to find answers to the following questions:

1. Do Yemeni EFL teachers use EFL games in their classes?

2. How and when do Yemeni EFL teachers perceive using games in their classes?

3. How do Yemeni EFL learners deem playing games in EFL classes?

4. What kind of games do EFL learners prefer?

\section{Literature Review}

\subsection{Learning Styles}

Learning styles are seen as one of the factors which determine how individuals learn a foreign language. The learning process of individuals is influenced by their style preferences. In this respect, Felder and Henriques(1995, p.21) view learning styles as "the ways in which an individual characteristically acquires, retains and retrieves information". Each learner has his /her own learning style preferences. "Learning styles are not dichotomous, but generally operate on a continuum or on multiple, intersecting continua" (Oxford, 2001, p.360). This means that an auditory learner may also be visual. Furthermore, he/she may be equally visual and auditory. Berman (1998) declares that in an average class of adults, twenty-nine percent will be predominantly visual learners, thirty-four percent auditory, and thirty-seven percent kinesthetic. These learning styles are always different in classes, and they vary as we move from one class to the next, so teachers are too required to vary their activities in a way that can cater to the needs and demands of most of the learners in class. In other terms, the activities should not be made in a way that serves the needs of some learners (visual ones) at the expense of others (kinesthetic ones).

\subsection{Learning Strategies}

Learning strategies are another variable that has some impact on learning. Research on second language learning strategies is mainly based on the studies of O' Malley and Chamot (1993). Broadly speaking, learning strategies are the cognitive steps that learners use to process second language input. These cognitive procedures include retrieving and storing new input.

O'Malley and Chamot categorize learning strategies under three headings (1993: 104):

1. Metacognitive strategies: Executive processes used in planning for learning, monitoring one's own comprehension and production, and evaluating how well one has achieved a learning objective.

2. Cognitive Strategies: Processes manipulating the material to be learned mentally (as in making images, inferring meaning, or elaborating on prior knowledge) or physically (as in grouping items to be learned or taking notes).

3. Social - Affective Strategies: Processes in which the learner is either interacting with another person, in order to assist learning, as in cooperative learning and asking questions for clarification, or using effective control to assist in learning tasks.

No strategy can be deemed as better than the other. What makes a strategy effective or ineffective is the condition in which it is being used. A strategy is useful under three conditions: "(a) the strategy relates well to the L2 task at hand; (b) the strategy fits the particular student's learning style preferences to one degree or another; and (c) the student employs the strategy effectively and links it with other relevant strategies" (Oxford, 1990, p. 8).

Each learner has his/her own strategy preferences, but mostly the learners employ them automatically. The teachers' job in terms of strategy preferences is to render students aware of learning strategies and apply the right strategies for the right $L 2$ tasks since there is enough evidence which indicates that effective strategy use makes language learning more effective.

\subsection{Theories of Play}

There are a number of theories that have advocated the use of play and stressed its positive effect on a human being physically and mentally, one of which is the "Increasing Power" theory of Spencer and Sheller (YEAR). This theory assumes that the main job of the activity of the play is getting rid of the increasing potential power of the human body which is considered as a biological operation that serves the living being. 
Crystal (1997) holds that learners very much prefer learning through playing as long as the latter helps them feel the enjoyment of practicing the different language skills instead of learning them in an outmoded way. He also feels that a child needs to practice "play" so that he/she can easily get integrated into a future life, whereby his/ her brain and nerve system, as well as other parts of his body, grow in a perfect and healthy way.

In the same vein, Piaget (YEAR) regards play as a suitable strategy that helps a great deal in developing a child's language and its structures. He takes for granted that by games, a child can expand his experiences and boosts his knowledge. Piaget considers "Problem Solving Games" which are given in the form of language problems as mental operations of different levels. He also deems "Word Forming Game" to be one of the language problem-solving games where letters can be added, omitted, or exchanged.

Piaget (1962) also suggests that cognitive development has a direct relation to the interaction that takes place between the child and the environment. Through this interaction with the latter, the child learns how to deal with and adjust to his/her environment. In his attempt to explain the play, Piaget (YEAR, PAGE) argues that:

1. Play is an indication of the child's growth and maturity.

2. Play is an essential prerequisite for a child's comprehensive growth.

3. Play develops the different phases of the child's growth.

For a deeper understanding of the term game or play, the following section will provide some definitions that better explain what games are.

\subsection{Definition of a Game}

Games have been used widely in a number of fields, including foreign language teaching. The present section is an introduction that tries to define the concept of the game and what has been said about its nature.

Celce Murcia et al. (1989) contend that the use of language in a game is an oriented task with a purpose to achieve. They argue that in games, language use takes precedence over language practice. In this sense, games help bring classroom activities closer to the real world, no matter how artificial they may be.

They also state that "the use of games, role-play, pair work, and other small-group activities have gained currency and is now widely recommended for inclusion in language teaching programs" (Celce Murcia et al., (1989, p. 16). According to them, certain games are good ways for practicing grammar points where the emphasis is placed on the formal dimension.

According to Haldfield (1999), "a game is an activity with rules, a goal and an element of fun. Games should be regarded as an integral part of the language syllabus, not as an amusing activity for Friday afternoon or for the end of the term."

The above definition shows the important position games occupy in foreign language teaching. Haldfield (1999) further confirms that "games can be used at all stages of the progression from controlled to free practice, serving at one end of the range as a memory aid and repetition drill, at the other as a chance to use the language freely and as a means to an end rather than an end in itself. They can also serve as a diagnostic tool for teachers, who can note areas of difficulty and take appropriate remedial action." Hadfield emphasizes the effective use of games. Because students sometimes may feel lazy to do the tasks assigned to them by the teachers, games are used as an alternative to go from forcing learners to engage unwillingly in dull activities to willingly and eagerly engaging in the practice or use of new language items they have just learned. Briefly put, it is more effective in a way that students can play and learn simultaneously.

Like Haldfield, Lee (1991: 3) defines games as: "being governed by rules". In addition to the above definitions, games also are used in EFL classes to create some sort of healthy competition.

\subsection{Games and the Element of Competition}

According to Greenall (1990: 6), "the term 'game' is used whenever there is an element of competition between individual students or teams in a language activity." When' an element of competition' appears, all the above rules are mostly needed. Besides, games are, in this case, emphasized to encourage students' solidarity in teamwork in which they have to try their utmost to do the tasks given in the games for their team spirit. Therefore, games comprise many factors such as rules, competition, relaxation, and learning. The main focus of using a game in class is not only to help students learn more effectively but also to have fun. There are many types of games, and the following subsection will shed light on most of them. 


\subsection{Categorizations of Games}

Hadfield (1999) puts forward two ways of categorizing language games. Firstly, language games are subdivided into two main types: linguistic games and communicative games. The first lays much emphasis on accuracy and the formal dimension of languages such as providing the correct tense verb, providing the correct synonym, and so forth, whereas the second, as the term suggests, stresses the practice and the amelioration of the communicative side of language, such as exchanging information and ideas in activities like information gap, role play, etc. Within this type, errors are tolerated by teachers as long as their ultimate purpose is communication, not language use.

Second, Hadfield (1999) classifies language games into more categories. Along with the categorizing of games as linguistic games or communicative games, some games will contain elements of more than one type, as follow:

\subsubsection{Information Gap Games}

Games like these require one or more people to have information that other people need in order to complete a task. For instance, one person might have a drawing and their partner needs to create a similar drawing by listening to the information given by the person with the drawing. Information gap games can involve a one-way information gap, such as the drawing game just described, or a two-way information gap, in which each person has unique information. This type of game gives learners a chance to practice the communicative language in a more realistic manner.

\subsubsection{Guessing Games}

These are a variety of information gap games. One of the best-known examples of a guessing game is 20 Questions, in which one person thinks of a famous person, place, or thing. The other participants can ask 20 Yes/No questions to find clues in order to guess who or what the person is thinking of. Such a game is considered engaging as it makes students do their best to win.

\subsubsection{Search Games}

These games are also another subtype of information gap games, with everyone giving and seeking information. Find Someone Who is a well-known example. Students are given a grid. The task is to fill in all the cells in the grid with the name of a classmate who fits that cell, e.g., someone who is a vegetarian. Students circulate, asking and answering questions to complete their own grid, and help classmates complete theirs.

\subsubsection{Structure Games}

Structure games are the ones that provide an experience of the use of particular patterns of syntax in communication.

\subsubsection{Vocabulary Games}

Another classification of games by McCallum (1980) consists of seven kinds: vocabulary games, conversation games, writing games, number games, Structure games, Spelling games, Roleplay, and dramatics.

The above classifications of games suggested by McCallum (YEAR) and Lee (YEAR) are considered known and popular as they are widely used to improve and enhance a language item or a skill while teaching learners a given lesson in class. Therefore, teachers should be careful in choosing the most appropriate game that fits the purpose of the lessons as well as the needs of the learners.

\subsection{The advantages of using games in FLT}

Wright et al. (1984) maintain that "language learning is hard work. Effort on the part of learners is needed at every moment and should be maintained over a long period of time. Games help and encourage many learners to sustain their interest and work." In addition, games help the teacher to create contexts in which the language is useful and meaningful. Games are used for a number of reasons and have a number of advantages.

In a somewhat similar manner, in their book "Games for Language Learning" Wright et al. (1984, pp. 1-2) also lists some major advantages of using games in foreign language classrooms:

1. Games help and encourage many students or learners to sustain their interest and work on learning a language.

2. Games can help teachers to create contexts in which language is useful and meaningful. Teaching English involves the teaching of patterns. These patterns can be taught meaningfully through games.

3. Games provide the repeated use of language form or drill. By making the language convey information and opinion, games provide the key feature of the drill with the opportunity to the work of language as living communication.

4. Games can be found to give practice in all the skills, in all the stages of the teaching-learning sequence, and for many types of communication. 
Brewster et al. (2002: 186-187) put forward a number of advantages of using games in language learning:

1. Games add variety to the range of learning situations.

2. Games change the pace of a lesson and help to keep students motivated.

3. Games 'lighten' more formal teaching and can help to renew students' motivation.

4. Games provide 'hidden' practice of specific language patterns, vocabulary, and pronunciation. Games can help to improve attention span, concentration, memory, listening skills, and reading skills.

Richard-Amato (1996) is of the opinion that even if games are often associated with fun, we should not ignore their pedagogical values, particularly in foreign language teaching and learning. For the above writer, games are effective thanks to their ability in promoting learners' motivation, relieve learners' stress, and, most importantly provide language learners with the opportunity for practicing foreign languages in real-life situations. Yet, there has been much prejudice that games are just for fun, not for educational purposes.

Though different in their ways of seeing the value of using games, the above linguists have a common point, in that they want what is best for their pupils: making learning a foreign language an easy task for their learners. In one way or another, the above linguists and researchers have emphasized the following advantages that result from the use of games in foreign language teaching. These are summed up as follows:

\subsubsection{Games Motivate Learners}

Searching for an efficient way through which learners are better motivated and encouraged has always been the pursuit and the interest of teachers, researchers, and linguists. In this regard, Hansen (1994, p. 118) suggests that "Games are highly motivating and entertaining, and they can give shy learners more opportunity to express their opinions and feelings."

Another similar view is expressed by Harmer (1998, p. 3), who affirms that "Motivation is some kind of internal drive that encourages somebody to pursue a course of action. The motivation students bring to class is the biggest factor affecting their success."

According to the above writers, games appear to create some motivation in learners for they are not only interesting and amusing, but they are simultaneously challenging, as well. One game is enough to get nearly all learners in a class to move around, activate, and stimulate their mental capacities. Even learners who are shy will be encouraged to attend the activities, thanks to the element of fun generated by the game being played. These learners' type will also forget their shyness and the anxiety they feel when learning a foreign language.

\subsubsection{Games Promote Learners' Interaction}

Pair or group work is one of the main ways to promote interaction. Such interaction is better achieved through the integration of game-like activities in class where students are invited to work together towards a common goal.

As Jacobs \& Kline Liu (1996) hold there are a number of games that lend themselves to be played in pairs or in small groups, giving an opportunity to students to work on their skills of disagreeing politely and the skill of asking for help while working together. Generally speaking, the learners of the gameplay may help students to be responsible toward the team in which everyone has a turn, encouraging everyone to take a turn, rather than letting others do all the talking and other actions, and discouraging one or two people from shutting out others.

\subsubsection{Games Improve Learners' Language Acquisition}

Avedon and Sutton-Smith (1971) remark that since the integration of games in foreign language learning happens to create a lot of motivation and interaction in foreign language learning classrooms, pupils' acquisition of the taught and presented lessons becomes more and easier to happen.

Furthermore, Richard-Amato (1996) emphasizes the fact that games can lessen anxiety and make the acquisition of foreign languages more possible. Such a relaxed atmosphere that games create in class makes it possible for learning to happen in a more spontaneous and relaxed way whereby students' retention of information becomes quicker and better.

From the above discussion, it appears that games are healthy teaching materials that help a lot of students develop their linguistic skills in group or pair work, in a way that is relaxed and fun. Besides improving their interaction, games help learners achieve progress in learning a foreign language in a relaxed and enjoyable manner. 


\subsection{How to Implement EFL Games in Class}

Rinvolucri (1990) defends the idea that games should be at the center of teaching a foreign language. In the case of teaching grammar, this author explains that a game can be employed in three stages while using them as a part of grammar instruction: before presenting a specific grammar structure, especially to check how much knowledge the learners already know, after a grammar presentation, to see how much the learners have understood, and as a way to revise the already-taught grammar points.

Teachers should also be aware of the various and different styles students have. Accordingly, it is the teacher's duty to find a game that meets all the needs of the learners, since preparing beforehand is necessary. Teachers have to attend to a number of things while using games in their classes.

In this regard, McCallum (1980) proposes a number of significant steps for teachers to follow. First, organizing the way the game will be played is the duty of the teacher. Second, before explaining the rules to the class, the teacher should first understand how the game is played, particularly when dealing with children. Third, the teacher should always be ready to adjust the game if anything new pops up in the class. Fourth, after selecting the game, the teacher should clarify its rules to the learners in a straightforward way. Fifth, giving a model or an example helps a lot of young learners grasp the rules in a clear and easy manner. Finally, the learners should not be interrupted every time they make mistakes.

For a good implementation of the game, McCallum (1980) asserts that learners have to be the same during the entire year as it both saves up the teacher's time and helps learners increase the team spirit that promotes an exchange of ideas among themselves. Working in pairs is also favorable as it boosts learners' communicative skills. In brief, dividing the class into pairs and groups improves learners' language and communication skills while engaging in competition among the teams or pairs. As such, the teacher may find more time to focus on students' language development. Games increase learners' proficiency in practicing language communicatively.

\subsection{Teacher Role in Using Educational Games}

Brewster et al. (2002) indicate that while the pupils are playing games, the teacher has a key role in observing and listening, monitoring pupils' language, giving prompts and explanations where necessary, noting pupils' language difficulties, which may need reteaching, etc. The teacher should not try to over-correct the children's mistakes if this is likely to spoil the flow of the game or reduce their enthusiasm.

Brewster et al. (2002, PAGE) think that the role of the teacher can be summarized as follows:

The Teacher:

1. Prepares in advance all the materials and items that will be needed.

2. Gives clear instructions to the pupils about the steps, procedures, rules grouping, and so on.

3. Circulates, monitors, guides, and helps the pupils throughout the game or activity.

4. Gives encouragement and praise and has a positive approach to error.

5. Provides clear feedback at the end of the game or activity when this is appropriate.

6. Varies the games and activities from lesson to lesson.

\section{Analysis and Evaluation of the Use of Games in Yemeni EFL Classes 3.1 Methodology}

This study uses both a qualitative and a quantitative methodology, with much focus on the former since this kind of study requires smaller but focused samples, rather than large samples.

\subsection{Instruments of the Study}

The quality of the drawn conclusions in this study will be dependent on the kind of study instruments used in the process of gathering data and information about the topic under study. I devised two questionnaires as instruments for collecting data. The first one is administered for EFL teachers, while the second questionnaire is intended for EFL learners in Yemen. There are two types of questionnaires: unstructured questionnaires which are based on open questions, giving more room for the respondents to answer in their own words, and structured questionnaires which are based largely on closed questions which produce data that lend itself to be analyzed quantitatively for patterns and trends. The questionnaire which is addressed to the learners is a structured one, while the questionnaire which is directed to the teachers is a semi-structured questionnaire because it combines both closed questions and open-ended questions, allowing the respondents to voice out their viewpoints freely. 


\subsection{Description of the Questionnaire}

The questionnaire that is addressed to the Yemeni EFL teachers can be subdivided into four parts. The introductory part is meant for the personal information of the respondents; it contains the teacher's gender, age group, teaching experience, place of work (city and institution), and qualifications. The second part is a kind of a frequency scale, and it is introduced by a question (cf. "How often do you use games in your class?)". The respondents respond to this question by ticking one of four boxes which represent the frequency scale (usually, sometimes, rarely, or never). The third part is also introduced by question (cf. "Do you think that EFL games...)" followed by six items pertaining to the various roles of games. The fourth part is made up of two open-ended questions. The first question is intended for Yemeni EFL teachers to state their opinions about other benefits and/or drawbacks of using EFL games, and the second is asked to find out when these teachers use EFL games.

The questionnaire that is devised for the Yemeni EFL learners can be divided into three main parts. In the introductory part, respondents are asked to fill out some personal information, such as their gender, years of English learning, age, and place of study (school and city). The second part comprises a series of closed questions that can elicit data that can be analyzed quantitatively for patterns and trends. Respondents are required to answer by "Yes" or "No", and if they have no idea, they respond by "I don't know". The third part includes five questions, all of which indicate the types of EFL games that learners prefer; respondents answer these questions by ticking either "Yes" or "No", and if they have no idea, they can tick "I don't know".

\subsection{Questionnaire Administration}

Regarding the procedure that I went through to gather data, twenty copies of the questionnaire were either given in person or sent to the respondents via email. As for the Yemeni EFL learners, one hundred copies of the questionnaire were handed out to high school students with various levels (First year, Second Year, and Third year at the high school) from two different public high schools (cf. Omer Al Mukhetar and Khawlah Bnt Al Azwar high schools). It was preferable to distribute and allow students to complete paper-based questionnaires out of class time since doing it in class would deprive learners of focusing on the lesson taught by the teacher.

\subsection{The participants}

Concerning the respondents, a total of twenty Yemeni EFL teachers with different qualifications took part in the survey from two high schools (cf. Omer Al Mukhetar and Khawlah Bnt Al Azwar high schools) in Amran city. Ten of the respondents are female teachers (50\%), and the other ten is male teachers (50\%). They were between 25 and 40 years old. These teachers were chosen on an academic and experience basis. In addition, to one hundred Yemeni EFL learners from the same high schools above within Amran, Thirty-five (35\%) of the respondents were male students, and sixty-five (65\%) were female students. The students are from different age groups; their ages range from fifteen to eighteen years old. They were chosen according to their levels of English learning. Twenty-five ( $25 \%$ ) of them have been learning English for four years (First year at the high school), thirty-two (32 \%) have been learning English for five years (Second year at the high school), and forty-three (43\%) have been learning English for six years (Third year at the high school).

\section{The Analysis of the Teachers' and Students' Questionnaire 4.1 Data Analysis}

The collected data is analyzed both quantitatively and qualitatively. The technique used to analyze data quantitatively is mechanical. I counted the number of similar responses provided by the respondents and then converted them into statistical figures. After all, the data is analyzed qualitatively to deduce answers to the study questions.

\subsection{Analysis of Teachers' Questionnaire}

In the current study, a total of twenty high school English teachers participated. Ten of the respondents are female teachers (50 $\%)$, and the other ten is male teachers (50\%). Their teaching experience ranges from two years to more than ten years. Four teachers have been teaching for two to four years, eight teachers have been teaching for five to ten years, and the other eight teachers have been teaching for more than ten years. Regarding their level of education, the teachers have different qualifications. Two of these teachers have M.A degrees with no pre-service training, five have B.A.s in degrees without pre-service training, and the other thirteen have B.A.s degrees with pre-service training.

The respondents were asked to fill out a semi-structured questionnaire that contains closed and open-ended questions. The first set of closed questions aims at finding out the frequency of EFL games used in some Yemeni EFL classes. The questions reveal the following results: 


\begin{tabular}{|l|l|l|l|l|l|}
\cline { 3 - 5 } & Usually & Sometimes & Rarely & Never \\
Hour often do you use games in & $\begin{array}{l}\text { Number of } \\
\text { teachers }\end{array}$ & 1 & 4 & 7 \\
\end{tabular}

The above figures show evidence that the alarming majority of the EFL teachers who took part in the study chose either the option 'never' or 'rarely' as an indication of using EFL games in their classes, whereas only a few teachers declare that they use games regularly. Four teachers sometimes use games and only one teacher usually employs the use of games.

In the "Elaborate" section, some teachers, especially the ones who opt for the option 'rarely' and 'never', affirm that the reason why they hardly ever use games in their classes is ascribed to large classes, lack of in-service courses that teach teachers on how to use games effectively in class.

The second set of closed questions is meant to investigate Yemeni EFL teachers' attitudes towards the various roles of EFL games have in EFL. The question shows the following results:

\begin{tabular}{|c|c|c|c|c|c|}
\hline Do you think that EFL games... & \multirow{5}{*}{$\begin{array}{l}\text { Number } \\
\text { of } \\
\text { teachers }\end{array}$} & Agree & $\begin{array}{l}\text { Agree to some } \\
\text { extent }\end{array}$ & $\begin{array}{l}\text { Disagree to } \\
\text { some extent }\end{array}$ & Disagree \\
\hline A. motivate EFL learners? & & 14 & 4 & 0 & 2 \\
\hline $\begin{array}{l}\text { B. encourage silent and reluctant } \\
\text { students to speak? }\end{array}$ & & 10 & 5 & 2 & 3 \\
\hline D. make the class more dynamic? & & 14 & 2 & 2 & 2 \\
\hline E. is just a waste of time? & & 1 & 0 & 0 & 19 \\
\hline
\end{tabular}

According to these results, EFL teachers in Yemen think positively of games. A great number of the respondents acknowledge the usefulness and utility of games, in that using them as instructional aids in EFL teaching brings about a number of benefits.

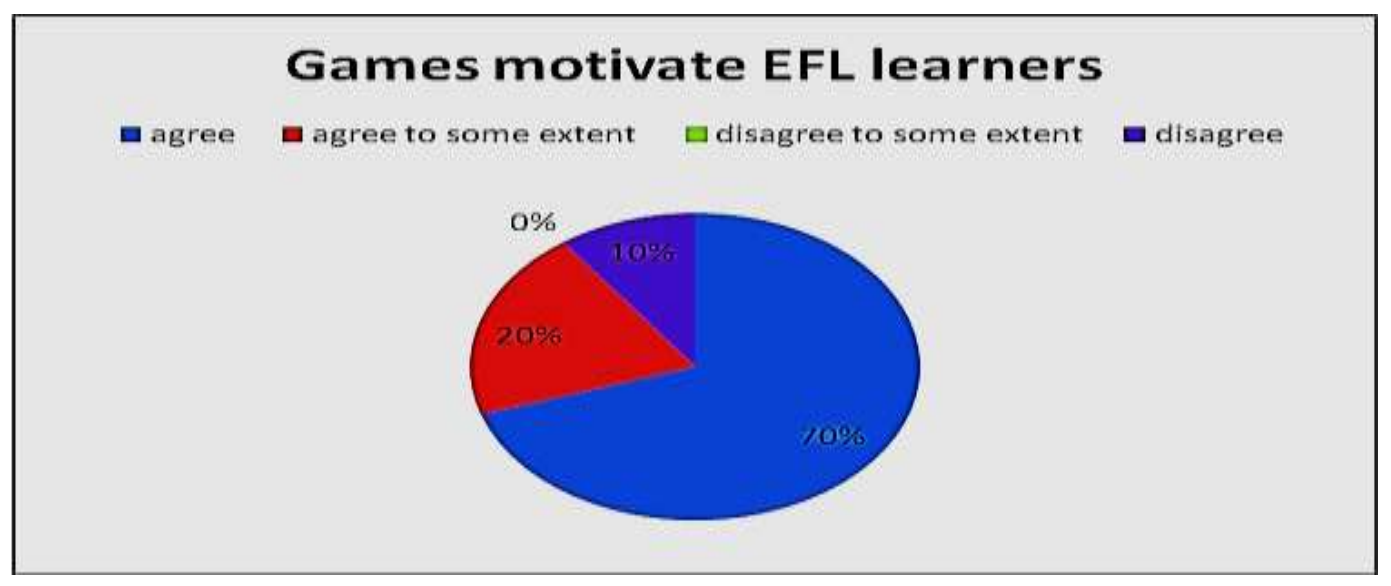

As the chart above clearly shows, the majority of the respondents agree that games serve as a key element to the motivation of EFL learners. This result is in accordance with the scheme of Hansen (1994) that games are highly motivating and entertaining, and they can give shy students more opportunities to express their opinions and feelings. 


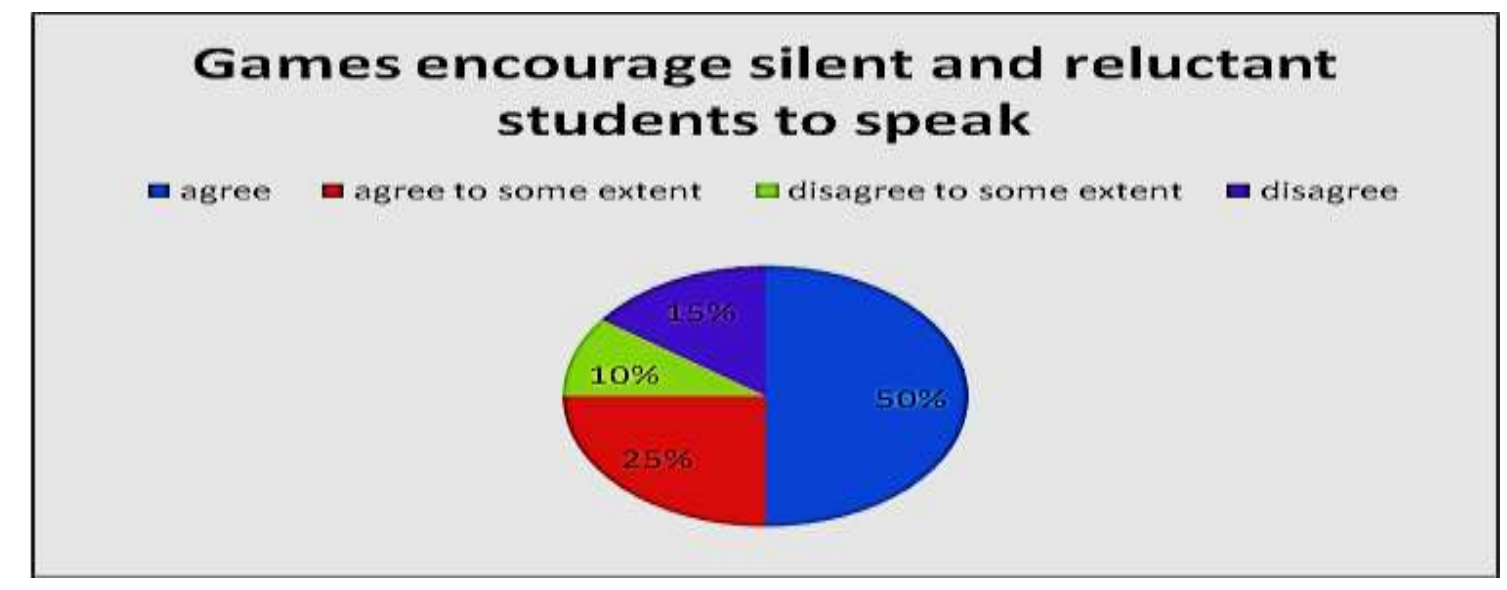

In addition, $50 \%$ of the respondents agree that games encourage silent and unwilling learners to speak the target language. When playing games, learners can learn English the way children learn their mother tongue without being aware they are studying. Thus, as Richard-Amato (1996) maintains, without stress, even shy students can participate positively.

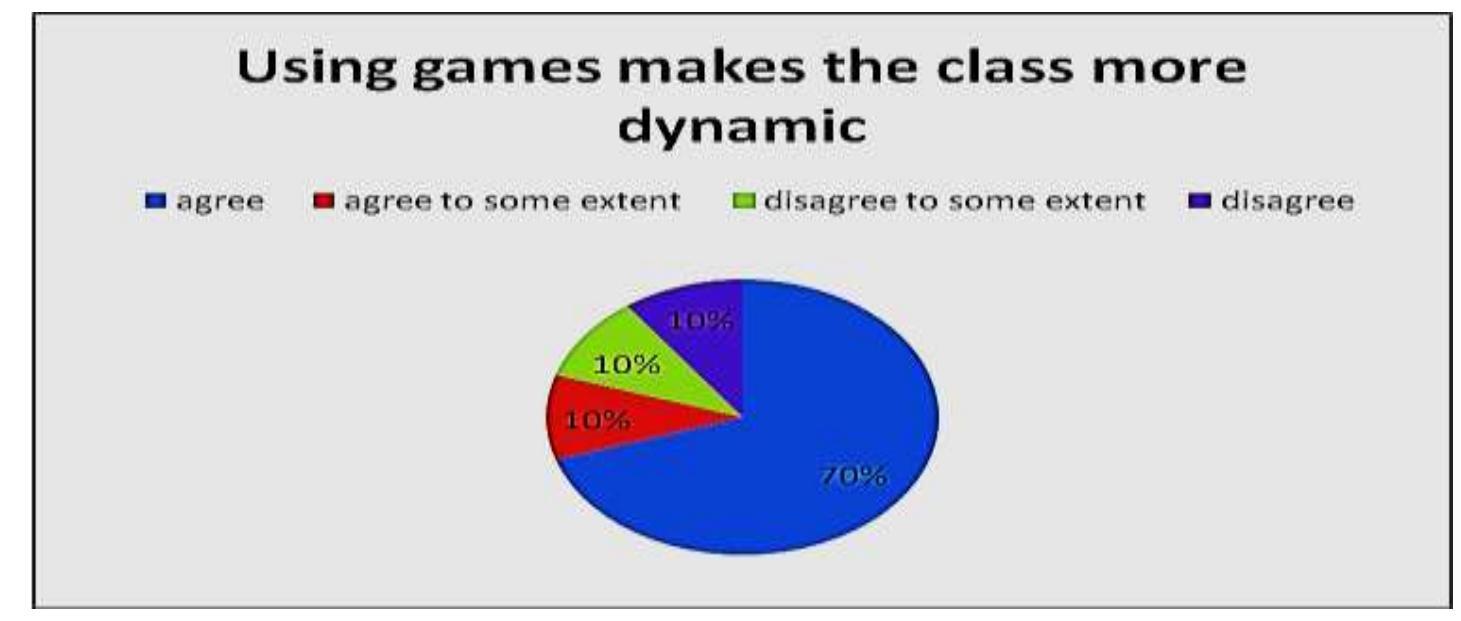

The above mentioned chart exhibits that a great proportion (70 \%) agrees that the use of EFL games makes the class more dynamic. Accordingly, classroom dynamics is the most important benefit of EFL games.

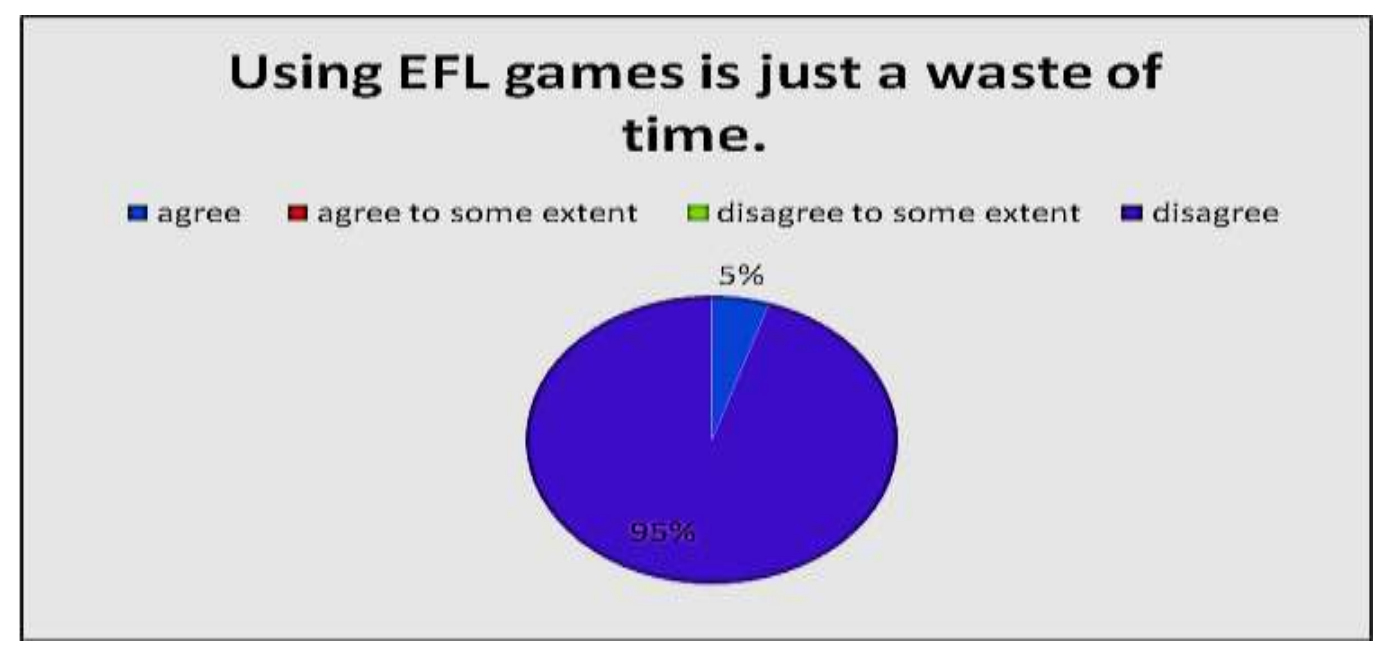

As for the drawbacks of EFL games, the great majority of the respondents opposed the idea that EFL games are just timeconsuming and useless teaching materials. Consequently, the above result refutes the view that says that EFL games are not serious learning activities, and the above result goes hand in hand with Kim (1995), who defends the view that it is rather possible to learn a language as well as enjoy oneself at the same time. 
In addition to the closed questions, there are two open-ended questions. The first question seeks to investigate teachers' viewpoints regarding other benefits and/or shortcomings of using games in EFL teaching. Statistically speaking, the majority of them (70\%) does not provide concrete examples of the benefits or pitfalls of EFL games. Still, two (10\%) of the teachers state that games can be of great use while teaching functions and spelling as in "Spelling B" games. Besides, one teacher (5\%) firmly believes that games belong to those kinds of learner-centered activities since they help shift the focus away from the teacher and thus minimize the teacher talking time and maximize the student talking time. They can often be organized in such a way that the learners have a leading role, while teachers stand just as facilitators. Another one (5\%) confirms that through playing games, students can learn English the way they learn their mother tongue without being aware that they are studying. Thus, with no stress accompanied to the learning process, students can do a lot better. Nevertheless, two other teachers (10\%) see that making use of games in the classroom has its shortcomings, too, since they consider games as an opportunity for disruptive behaviors to happen.

The above-mentioned results indicate that some EFL teachers, though a minority, believe that EFL games belong to those kinds of learner-centered activities since they can help to shift away from the focus from the teacher to the learner. Likewise, Millis (2005) describes EFL games as student-centered in that students are active in playing the games, and games can often be organized in such a manner that students have the leading roles, with teachers as facilitators. Moreover, another minority affirms that EFL games help a lot in fluency-oriented activities as students speak the language without paying too much attention to errors at the level of grammar or structure. In a somewhat similar manner, Lee (YEAR) holds that most language games make learners use the language instead of thinking about learning the correct forms.

The second open question is meant to discover the times at which Yemeni EFL teachers can employ games. Responses to this question show that the majority of the teachers can use games as time fillers, ice breakers, or warm-up activities. Also, some teachers assume that games can be used at the end of the units of English Textbooks as a reward for students when they see that they have worked hard and need some refreshment.

Accordingly, it can be inferred that games, if used, are mostly used for filling the time or entertainment not principally for purely didactic purposes, which is a direct indication that several of the respondents lack the needed proficiency to exploit games for different didactic goals.

\subsection{The Analysis of the Students' Questionnaire}

In parallel, the survey of the Yemeni EFL learners involved one hundred students from two different public high schools within Amran. Thirty-five (35\%) of the respondents were male students, and sixty-five (65\%) were female students. The students are from different age groups; their ages range from fifteen to eighteen years old. They have different levels of English learning Twenty-five ( $25 \%$ ) of them have been learning English for four years (First year at the high school), thirty-two (32 \%) have been learning English for five years (Second year at the high school), and forty-three $(43 \%)$ have been learning English for six years (Third year at the high school).

The Yemeni EFL learners are asked to fill out a questionnaire that consists of two sets of closed questions. The first set of questions is meant to show the learner's attitudes towards the use of games in EFL classes. The responses to these questions can be tabulated as follows: 


\begin{tabular}{|c|c|c|c|c|}
\hline & & & & \multirow{3}{*}{$\begin{array}{l}\text { I don't know } \\
8 \mathrm{Ss}\end{array}$} \\
\hline \multirow{2}{*}{ Do you like to play language games in the English class? } & \multirow{2}{*}{$\begin{array}{l}\text { Number of } \\
\text { students }\end{array}$} & \multirow{2}{*}{\begin{tabular}{|l} 
YES \\
$90 \mathrm{Ss}$
\end{tabular}} & \multirow{2}{*}{$\begin{array}{l}\text { NO } \\
2 \text { Ss }\end{array}$} & \\
\hline & & & & \\
\hline Are games as important as grammar exercises? & & $32 \mathrm{Ss}$ & $30 \mathrm{Ss}$ & $38 \mathrm{Ss}$ \\
\hline Do games help you learn English through fun? & & 47 Ss & $11 \mathrm{Ss}$ & 42 Ss \\
\hline $\begin{array}{l}\text { Do you get encouraged to speak English when playing a } \\
\text { game in the classroom? }\end{array}$ & & 65 Ss & 15 Ss & 20 Ss \\
\hline
\end{tabular}

\section{Do you like to play language games in the English class?}

$\square$ YES $\square$ NO $=$ DON'TKNOW

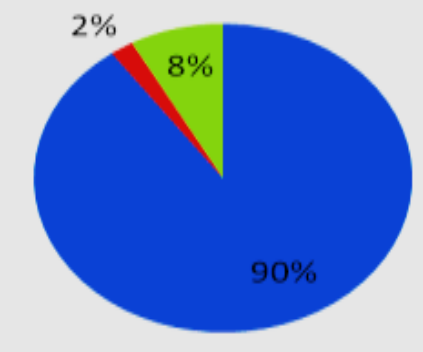

Responses to the first questions clearly indicate that EFL learners have a positive attitude towards EFL games. As one can see from the above chart, the great majority of the respondents like playing games. This is attributable to the fact that the games help motivate learners to learn more when they are taught in the dry and serious old fashionable way.

\section{Are games as important as grammar exercises? \\ $=$ YES $=$ NO $=$ DON'TKNOW}

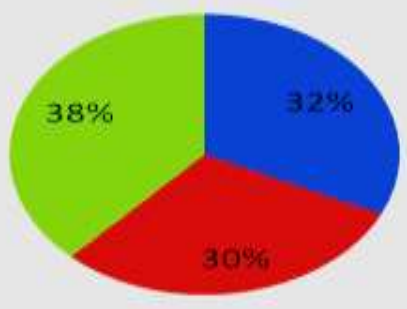


Furthermore, a quite considerable proportion (32\%) believes that games are as important as grammar exercises. This result corresponds to the view of Wright et al. (YEAR), that a game context makes the foreign language immediately useful to the learners, especially the young ones. It brings the target language to life; therefore, it is considered to be beneficial as a grammar activity.

\section{Do games help you learn English through fun?}

$\because$ YES $\square$ NO DON'TKNOW

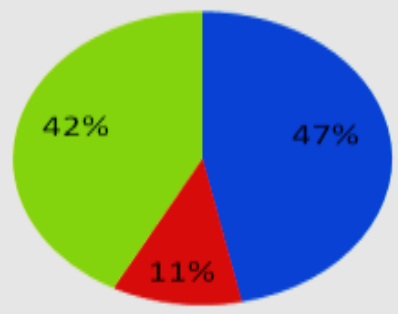

In addition, another considerable proportion confirms that games help to learn English through fun. Likewise, Hadfield (YEAR) holds that games bring in relaxation and fun for students, thus helping them learn and retain new words more easily. Consequently, EFL games can have a positive affective influence on the learners which makes the learning process much easier.

\section{Do you get encouraged to speak English when playing a game in the classroom?}

- YES $\square$ NO IDON'TKNOW

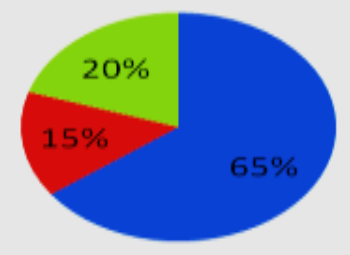

Besides, a great part of the respondents (65\%) believes that games encourage them to speak English. The reason behind that is that games contribute to reducing levels of learner anxiety. Anxious students have lower levels of verbal production and are reluctant to personally express relevant information in an EFL conversation. So, games can reduce the levels of worry by offering the learners a stress-free and peaceful learning environment, thus encouraging, entertaining, teaching, and promoting fluency. Furthermore, when playing games, learners stop thinking about language and begin using it in a spontaneous and natural manner within the classroom.

The second set of questions inquire about determining the types of games that Yemeni EFL learners prefer. The learners' answers to these questions reveal the following results: 


\begin{tabular}{|c|c|c|c|c|}
\hline Do you prefer the games which... & $\begin{array}{l}\text { Number } \\
\text { Of Students }\end{array}$ & YES & NO & I don't know \\
\hline are played in groups? & & $41 \mathrm{Ss}$ & 32 Ss & $27 \mathrm{Ss}$ \\
\hline are played in pairs? & & $45 \mathrm{Ss}$ & $38 \mathrm{Ss}$ & $17 \mathrm{Ss}$ \\
\hline are whole-class games? & & $23 \mathrm{Ss}$ & $64 \mathrm{Ss}$ & $13 \mathrm{Ss}$ \\
\hline competitive? & & $52 \mathrm{Ss}$ & $23 \mathrm{Ss}$ & $25 \mathrm{Ss}$ \\
\hline
\end{tabular}

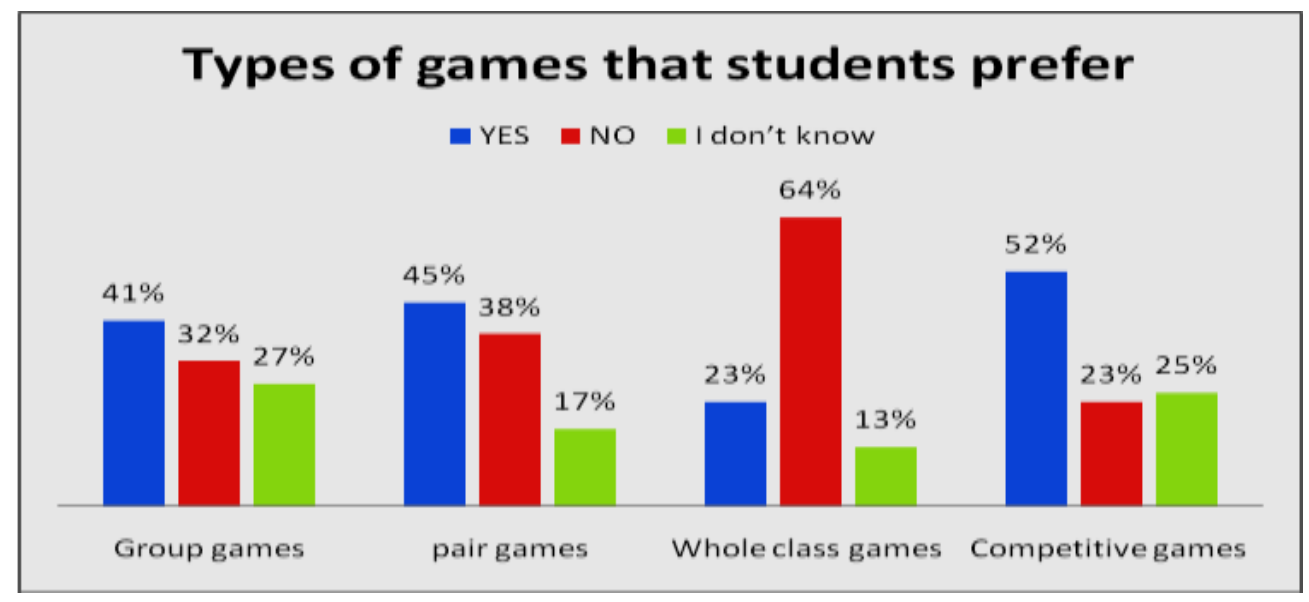

The results reveal that the most fascinating type is competitive games. Competitiveness is an important element that is brought to the classroom by EFL games. Nevertheless, many teachers do not like competitive games. Sharp competitiveness might sometimes result in conflicts among learners. To overcome such problems, however, teachers can use the following competitive elements: "class vs. teacher" and "class vs. time". "Class vs. teacher" games are an excellent way to include a competitive element. Often, even the quietest students get "caught up" in the excitement of the game and participate; whereas, "class vs. time" games give a competitive feel to activities but still give each group a chance to win. Setting a realistic, yet challenging time limit for an activity can add an element of urgency. Many students enjoy trying to improve on previous performances.

Moreover, group games (52\%) and pair games (45\%) come second in terms of students' preferences. This means that students like to play the type of games that provide a kind of security. In this respect, Millis (2005) outlines a number of advantages of cooperative games, such as appropriate anxiety levels and more constructive feedback. This implies that teachers should bring a variety of games in order to satisfy their students' needs. Thus, the learners' viewpoints towards the use of games in Yemeni EFL classes are reasonably positive, which entails that teachers should take games as serious instructional materials, not trivial ones.

\subsection{Recommendations and Classroom Applications}

Now that it has been analytically proven that Yemeni EFL learners and teachers have positive attitudes towards the use of games in EFL teaching and learning, EFL teachers in Yemeni public schools are crucially recommended to deal with EFL games as central instructional materials and use them very often. Games should not be regarded as marginal activities filling in odd moments when the teacher and class have nothing better to do. They ought to be at the heart of EFL teaching.

Furthermore, Yemeni EFL teachers are recommended to extend their knowledge about how to use games appropriately. Beforehand preparation is one of the essential elements for the efficacy of games in EFL teaching. Before deciding to use a game, teachers are recommended to assure that the game must be more than just fun, involve "friendly" competition, keep all of the students involved and interested, encourage students to focus on the use of language rather than on the language itself, and give students a chance to learn, practice, or review specific language material. 
Additionally, teachers should not consider the noise that games result in as an excuse to stop using them. It is true that some games result in noise; however, EFL teachers are required to distinguish healthy noise from chaos. Yet, games result in healthy noise but create an enjoyable learning atmosphere, they are still worth paying attention to and implementing in the classroom since they motivate learners, promote communicative competence, and generate fluency.

In the same vein, grouping plays an essential role in the success of the chosen EFL game. When deciding on an appropriate grouping, teachers are highly recommended to consider the dynamics of their classroom. Although often overlooked, classroom dynamics is an important element. Success depends less on materials, techniques, and more on what goes on between the people in the classroom. To be used successfully, groups need to be well-thought-out. Then, it is recommended to form groups that create anxiety-free relationships and situations.

All in all, Yemeni EFL teachers are highly advised to use EFL games for they encourage, entertain, teach, and promote fluency. If not for any of these reasons, they should be used just because they help students see beauty in a foreign language and not just problems that at times seem overwhelming.

The following EFL games are recommended to be used in class and they are suggested by Wright et al. (1984). They are as follows:

\subsubsection{The Coffee pot Game}

This is a traditional but fun game to play: one student is sent out of the class and the remaining students choose a simple verb (e.g. "walk", "eat", "dance", etc.). The student that is outside then returned and has to find out which is the "mystery" verb by asking yes-no questions to the other students. The word "coffeepot" is provided to substitute the verb. The student then asks: "Do you coffeepot every day?"; "Do you coffeepot with your legs?" until he/she finds out which is the mystery verb.

\subsubsection{Ball Game}

Students stand up in a circle around the teacher. A ball is tossed to a student and the teacher asks a question, e.g., "Say a color". The student then responds and throws the ball back to the teacher. The teacher then throws the ball to another student and asks another question. For higher levels, you can ask such questions like "Give me the past participle of an irregular verb". This is a fast game, and it is great for reviewing vocabulary.

More games are suggested by Hewitt (1996). They are as follows:

\subsubsection{Last Letter}

This is actually a variation from the Ball Game. The last letter of the word must be the first letter of the next word. You will need a ball, but a screwed-up piece of paper is fine. The teacher throws the ball to one student and says a word, such as "dog". The student must reply with a word starting with "G," such as "girl". When answered, the ball is thrown back to the teacher and it is then thrown to the next student, who continues. The sequence may then be (for example): girl, look, king, go, octopus, student, etc. You can have the students throwing to each other, i.e., student $A=$ "Cat," throw to student $B=$ "Today," throw to student $C=$ "Yes," etc. Please be warned you may have some fastball pitchers in the class!

\subsubsection{Word Association}

The teacher starts the game by saying a word, such as "Hotel". For example Teacher: Hotel Student A: Bed Student B: Room Student C: Service Student D: Food Student E: Restaurant Student F: Chinese As you can see, any association is ok. If the student can't answer (5-second limit) he or she must stand up. The last student seated is the winner. If the association is not obvious, the student is asked to explain the association.

\subsubsection{What's Behind You (Memory Game)}

Tell the class not to turn round. Ask them what they think is behind them. They might list other people in the class, furniture, pictures on the walls, etc. Ask for descriptions for the things they mention. The teacher may also ask what the learners can remember of the street outside the school, e.g. Teacher: Think about the street outside the school. What can you remember? Student: There are some trees... Teacher: Are there trees on both sides of the street? ... In a variation of this game, a student is asked to close his eyes and describe his neighbor's appearance.

\subsubsection{What Am I?}

Get a few blank adhesive tags and write random nouns on them, then have the students stand up. Paste a tag on the forehead of each student. They have to walk around the class asking yes/no questions until they find out which noun they have on their foreheads. A variation of this game would be using the names of famous people. 


\section{Conclusion}

This study was an attempt to answer a series of questions. The questions were addressed to the Yemeni EFL teachers and learners in order to find out their attitudes towards the use of games in Yemeni EFL classes. More specifically, I tried to see whether Yemeni EFL teachers use EFL games in their classes, how they perceive using games in their classes, and when they use EFL games. On the other hand, I tried to investigate how Yemeni EFL learners deem playing games in the EFL classes and distinguish the types of games they prefer.

To reach this end, I divided my study into two major parts. In the first part, I tackled the issue of using games in EFL classes theoretically. In doing so, I defined EFL games in a way that strongly relates to EFL teaching and learning, showing the common types of EFL games. In addition, I stated some of the benefits of using games in EFL classes. I also showed the criteria and the way games should be used in EFL games. In the second part, the main concern was to analyze the data gathered through the questions of the research study. In so doing (Be consistent in your style), I tried to find out whether Yemeni EFL teachers are aware of the benefits games provide. I also tried to see the extent to which these teachers employ EFL games in their classes. Then, I tried to determine the EFL learners' viewpoints towards using EFL games in EFL learning. After that, I made an attempt to have a clear idea about the types of games they generally prefer.

The surveys provided considerable answers to the study questions. The results were as follows: Yemeni EFL teachers have positive attitudes towards EFL games yet, they hardly ever use them. The majority treats them either as time fillers or routine breakers. Yemeni EFL learners, on the other hand, are so welcoming to the idea of learning English through EFL games. The great majority of them have positive attitudes towards playing EFL games. Still, the Yemeni EFL teachers involved in the research seem to lack the right proficiency to use games in appropriate manners.

All in all, it is worth mentioning that there is much left to investigate regarding the reasons which prevent Yemeni EFL teachers from treating games as serious instructional materials. In this regard, Yemeni educationalists, instructors, education researchers, and stakeholders are invited to investigate the issue. Also, it is highly advisable that my country should organize some conferences and seminars in which EFL teachers have some workshops about the use of games in Yemeni EFL classes. Finally, Yemeni inspectors of education should organize in-service programs for EFL teachers to help them use techniques like games in their classes.

\section{References}

[1] Avedon, E. M. \& Sutton-Smith, B. (1971). The study of games. London: John Wiley \& Sons.

[2] Brewster, J., Ellis, G., Girard, D, (2002). The Primary English Teacher's Guide. Essex: Penguin English.

[3] Celce-Murcia, M. Intosh, Lois Mc, (1989).Teaching English as a Second or Foreign Language. U.S.A: Newbury House Publisher, Inc.

[4] Crystal, D. (1997). Cambridge encyclopedia of language (2nd ed.). Cambridge: Cambridge University Press.

[5] Felder, R. M. and E., Henriques. (1995), "Learning and teaching styles in foreign and second language education". Foreign Language Annals, 28 (1), 21-31.

[6] Greenall, S., (1990). Language games and activities. Hulton educational publications Ltd, Britain.

[7] Hadfield, J. (1999). Intermediate vocabulary games. Harlow, Essex: Longman.

[8] Hansen, M. (1994). The use of games for vocabulary presentation and revision. Vol 36 No 1, January, March 1998.

[9] Harmer, J. (1998). How to teach English. London: Long man.

[10] Hewitt, I. E. (1996) Edutainment- $H$ to teach the language with fun and games, Language Direct, Australia.

[11] Jacobs, G. M., \& Kline-Liu, K..(1996). Integrating language functions and collaborative skills in the second language classroom. TESL Reporter, 29(1), 21-33.

[12] Kim, L. (1995). Creative games for the language class.ET Forum, 33(1), 35-36.

[13] Lee, W. R. (1991). Language teaching: Games and Contests. Oxford: Oxford University Press.

[14] Millis, B. (2005). The educational value of cooperative games. IASCE Newsletter, 24(3), 5-7.

[15] MCcallum, G. P. (1980). 101 Word Games.1st Edition. USA: Oxford University Press.

[16] O, Malley, J.M. and A.U., Chamot. (1993): Learner Characteristics in Second-language acquisition. In Liyanage I.J.B. (2004).

[17] Oxford, R., L. (1990): Language Learning Strategies: What Every Teacher Should Know. Boston: Heinle\&Heinle.

[18] Oxford R., L. (2001): Language Learning Styles and Strategies. In M. Celce -Murcia. (ed.) Teaching English as a Second or Foreign Language Teaching. Heinle \& Heinle: USA.

[19] Piaget, J.-P. (1962). Play, dreams, and imitation in childhood. Norton, New York.

[20] Richard-Amato, P.A.. (1996). Making it happen: Interaction in the second language classroom (2nd ed.). New York: Longman.

[21] Rinvolucri, M. (1990).Grammar Games: Cognitive, affective, and drama activities for EFL students. Cambridge: Cambridge University Press.

[22] Rixon, Shellagh. (1981). How to use Games in Language Teaching. London: Macmillan Publishers Ltd.

[23] Wright, A., Betteridge, D., \&Buckby, M. (1984).Games for language learning. New York: Cambridge University Press. 